\title{
Anabases
}

ANABASES Traditions et réceptions de l'Antiquité

$25 \mid 2017$

Varia

\section{Ana IRIARTE y Luísa DE NAZARE FERREIERA (coords.), Idades e género na literatura e na arte da Grécia antiga}

Borja Mendez Santiago

\section{OpenEdition}

\section{Journals}

Edición electrónica

URL: http://journals.openedition.org/anabases/6139

DOI: 10.4000/anabases.6139

ISSN: 2256-9421

Editor

E.R.A.S.M.E.

\section{Edición impresa}

Fecha de publicación: 1 abril 2017

Paginación: 288-290

ISSN: 1774-4296

\section{Referencia electrónica}

Borja Mendez Santiago, «Ana IRIARTe y Luísa de nAZARe ferReiera (coords.), Idades e género na literatura e na arte da Grécia antiga», Anabases [En línea], 25 | 2017, Puesto en línea el 01 abril 2017, consultado el 20 enero 2021. URL: http://journals.openedition.org/anabases/6139 ; DOI: https://doi.org/10.4000/ anabases.6139

Este documento fue generado automáticamente el 20 enero 2021

(c) Anabases 


\title{
Ana IRIARTE y Luísa DE NAZARE FERREIERA (coords.), Idades e género na literatura e na arte da Grécia antiga
}

\author{
Borja Mendez Santiago
}

\section{REFERENCIA}

Ana IRIARTE y Luísa DE NAZARE FERREIERA (coords.), Idades e género na literatura e na arte da Grécia antiga

Coimbra, 2015, 218 p.,

ISBN : 978-989-26-1016-0

1 El presente volumen, compuesto de siete aportaciones, busca analizar la interrelación entre las diferentes categorías de género y de edad centrándose en los ignotos márgenes que, desde la historiografía tradicional, han sido soslayados al erigir en protagonistas al ciudadano en edad de combatir y, en grado menor, a la esposa oficial en edad de procrear. Privilegiando dichos márgenes, los trabajos aquí presentados enfocan la representación del universo infantil desde la perspectiva de una violencia inusitada desde nuestros nuevos parámetros sociales. Asimismo, a lo largo del volumen se evoca con frecuencia la ambigüedad de la figura del adolescente. En la franja de edad opuesta, encontramos la también ambigua ancianidad, situada a caballo entre el desdoro de una vejez improductiva en términos militares, laborales y reproductivos, y el inestimable valor que se le reconoce en la antigüedad en tanto depositaria de experiencia y saber.

2 Ana Iriarte, en «Semblanzas de semi-ciudadanas griegas. Sobre críos, ancianos y féminas », señala la importancia de la oposición etarea y sexual en el escenario teatral ático. Una vez subrayada la importancia otorgada por los dramaturgos griegos a esta doble diferenciación, Solón, Aristóteles y Plutarco sirven de guías a la hora de establecer el « listado » de los distintos colectivos de edad que rodeaban al grupo social 
hegemónico de la sociedad griega : el integrado por los ciudadanos de pleno derecho. La autora, que no pretende otra cosa que recordar de cuántas maneras se puede no-ser "absolutamente ciudadano", destaca el papel de unas mujeres que, pese a no ser ciudadanas, sí transmitían el estatus de ciudadanía a los hijos habidos en el contexto del matrimonio legítimo.

3 A continuación, Margarita Moreno, en « Las edades de la vida : infancia y vejez a través de la iconografía griega » se centra en demostrar que "Grecia es [era] un mundo dicotómico de hombres y mujeres ya desde la cuna» (p. 31). Así, tras establecer elaboradas contraposiciones entre la información sobre los ritos asociados a los niños varones y la visible desinformación que planea sobre la infancia femenina en Grecia, la autora incide en la diferente educación de unos y otros: mientras que las niñas comenzaban a aprender las que en adelante serían sus tareas dentro del oikos, los varones se adentraban en una instrucción tanto física como intelectual tendente a formarlos como futuros ciudadanos y hoplitas. El capítulo, que también analiza la escasa atención recibida por la vejez en las obras griegas, termina con una reflexión inquietante que une a los dos extremos de la vida en su faceta de potenciales receptores de violencia.

4 Luisa de Nazaré, en "Violência e infância na Grécia antiga: três aspectos de uma problemática ", aborda el papel activo de niños y jóvenes en unas conductas de tipo violento cuyas manifestaciones más palpables son, por un lado, el maltrato a animales $y$, por otro, el cuestionamiento de la preponderancia de los adultos; es por ello que en las fuentes literarias se consigna habitualmente la necesidad de corregir físicamente a los jóvenes, aspecto que es analizado aquí a través de unas fuentes iconográficas que nos permiten observar cuáles eran las principales medidas represoras utilizadas en el contexto educativo por la sociedad griega, así como los convencionalismos artísticos imperantes, entre los que sobresale la representación del infante (siempre varón) como un « adulto en miniatura ».

5 A renglón seguido, Katia Obrist, en « El hogar campesino para la doncella en Trabajos y Días de Hesíodo ", analiza el papel de la mujer en una de las obras fundacionales de la literatura griega. Así, una vez descritos los principales cambios producidos durante el arcaísmo griego, se analiza la construcción cultural de una « ideología de la diferencia » que establece, al menos idealmente, unos roles sociales, políticos y económicos bien diferenciados en función del género. La mujer, identificada con una tierra cada vez más valiosa, deberá ser «domesticada» por un varón que comienza a temerla de una manera compulsiva. En adelante, las mujeres (aristocráticas), privadas de toda labor exterior, tan solo podrán trabajar y contribuir a la economía familiar desde el interior de sus casas.

6 En « Maneras rituales de matar a una doncella: Ifigenia entre las víctimas sacrificiales euripideas ", Elsa Rodríguez clarifica el papel jugado, en algunas tragedias griegas, por las jóvenes que van a ser sacrificadas. En este sentido, tras destacar la relación existente entre la violencia y lo femenino en el registro clásico, así como la animalización de las víctimas sacrificiales antes de ser ejecutadas, se abordan aspectos de tanto interés como la (aparente) aceptación del sacrificio por parte de unas vírgenes que se limitan a ejercer un papel pasivo en las tragedias, o el nexo existente entre las mismas y Ártemis, en tanto diosa de los márgenes que protege a las doncellas antes del matrimonio. 
7 Nuno Simões analiza, en « Problemática da prostituição masculina na Atenas clássica », una institución pederástica que es estudiada como comportamiento típico de unas élites (aunque no exclusivamente suyo) que buscaban, a través de la misma, perpetuar un contexto socio-cultural favorable a sus propios intereses. Tras poner de relieve la jerarquización de las uniones entre erastés y erómenos, el autor explica la necesidad griega de sujetar estas prácticas a unas estrictas reglas de moralidad. A continuación se analiza la prostitución masculina en sus distintas vertientes destacándose, a través del Contra Timarco de Esquines, las consecuencias que el ejercicio de la prostitución podía conllevar para un ciudadano ateniense: la atimia, esto es, la pérdida total de sus derechos políticos.

8 Para finalizar, Marta González estudia la representación de la vejez en los epigramas funerarios griegos de época clásica en «Eudaímones. Dichosos ancianos del Ática ». Después de una breve mención al mito de Titono y partiendo de la irrupción de los estudios sobre la senectud en el mundo antiguo a partir de la obra de M.I. Finley, la autora analiza un corpus de estelas funerarias dedicadas a individuos ancianos de ambos sexos haciendo hincapié tanto en los adjetivos que emplean como en sus formas de representación. Así, mientras que las imágenes de varones sí marcan la edad del difunto, la apariencia de las mujeres ancianas no varía respecto a la de las mujeres en época fértil. Como resume la autora, «al igual que no hay ciudadanas, no hay ancianas equivalentes, socialmente, a la clase de los gérontes » (p. 187).

9 Nos hallamos, pues, ante un estudio de historia social y cultural sumamente novedoso ya que incide en unos aspectos etarios frecuentemente soslayados por una historiografía que, hasta hace muy poco tiempo, no se había interesado por este tipo de temas. Asimismo, ha de destacarse la exhaustiva búsqueda bibliográfica realizada por los autores de este libro colectivo que se erige, por méritos propios, en una referencia ineludible para todos aquellos investigadores e investigadoras que quieran acercarse a la realidad social del mundo griego desde una perspectiva novedosa a la par que metodológicamente rigurosa.

\section{AUTORES}

BORJA MENDEZ SANTIAGO

Universidad de Oviedo

uo196561@uniovi.es 